\title{
SILICON CONSUMPTION AND POPULATION DENSITY CHANGES OF DOMINANT FLANKTONIC DIATOMS IN LAKE CONSTANCE
}

\author{
U. SOMMER AND H.-H. STABEL \\ Limnological Institute, University ofConstance, D-7750 Constance, West Germany
}

\section{SUMMARY}

(1) Interactions between silicon concentration and diatom growth have been studied in Lake Constance with data on number and volume of cells per unit volume of water and concentration of dissolved reactive silicon.

(2) Concentration of dissolved reactive silicon was found to decrease markedly during the spring and summer growth period of diatoms in 1979 and 1980.

(3) Amounts of silicon taken up per cell and per unit cell volume have been calculated from the changes in silicon concentration and the increases in population density for several diatom species. The silicon to cell quotient (mg per million cells) varied over a wide range from 0.005 for Stephanodiscus hantzschii to 0.72 for Synedra acus, while that of silicon per unit cell volume (mg mm-3) varied over a narrower range from $0 \cdot 10$ for Stephanodiscus hantzschii and Fragilaria crotonesis to 0.36 for Synedra acus.

(4) A four-compartment model, that allows estimates ofthe rates of growth and ofloss of diatom populations to be calculated, is outlined.

(5) Summer succession from Asterionellaformosa to either Fragilaria crotonensis (in 1979) or Stephanodiscus binderanus (in 1980) is explained by interspecific differences in the effects of silicon concentration on growth and death. For Asterionellaformosa, silicon depletion did not stop cell-division but led to the death of most of the population. For Fragilaria crotonensis and S tephanodiscus binderanus cell division stopped but cells did not die and population growth continued after the concentration of dissolved silicon had increased again.

\section{INTRODUCTION}

In many lakes, growth of planktonic diatoms has been closely interrelated with the concentration of dissolved silicon. Diatom growth leads to the removal of silicon whose depletion may result in a decline in diatom population density (Baumert 1979). Some information is available on the silicon content of different diatom species, partly derived from field data and partly from culture sturlies (Einsele \& Grim 1938; J0rgensen 1955; Hughes \& Lund 1962; Happey 1970; Bailey-Watts 1976a). Lund (1950) and La Zerte (1980) have studied populations of single species of diatoms and their control by environmental factors, with emphasis on siticon availability. In Lake Constance, as in many other lakes, the simultaneaus abundance of several diatom species during a period of silicon depletion makes analysis of diatom-silica interactions more complicated. We attempt here to explain the succession in diatom dominance during a period of silicon depletion by interspecific differences in the reaction of diatoms to decreasing concentration of dissolved reactive silicon.

Two explanations for the observed species succession in diatoms are tested. First, there is the possibility of a sequence from species with high silicon consumption to species wlth low silicon consumption during periods of declining concentration of dissolved silicon. This hypothesis is tested through calculation of the silicon consumption per cell and per unit cell 
volume. Secondly, interspecific differences could exist in the reaction of diatom species to periods of extremely low silicon concentration through changes in growth rate or through persistence or death. Lund (1950) has shown that severe depletion of silicon leads to death of Asterionella formosa Hass. A capability to endure periods of silicon deficiency could enable other species to succeed Asterionella formosa when silicon concentration rises again. To test this hypothesis, growth and loss rates for the periods in question have been calculated with the help of a simple multi-compartment model.

\section{THE STUDY SITE}

Lake Constance is a mesotrophic lake of $500 \mathrm{~km}^{2}$ surface area and maximum depth $250 \mathrm{~m}$, situated on the northern fringe ofthe Alps $\left(47^{\circ} 40^{\prime} \mathrm{N}, 9^{\circ} 15^{\prime} \mathrm{E}\right)$. Stabel \& Tilzer (1981) give data on physico-chemical variables and Mohammed \& Müller (1981) on phytoplankton and nutrient concentrations. Despite temporary Iimitation of diatoms by silicon, growth of phytoplankton in general is phosphorus-lirnited during summer. A description and analysis ofthe algal species succession has been given by Sommer (1981a, b).

\section{METHODS}

\section{Sampling}

Sampies were taken weekly at depths of $0,1,2,3,4,5,6,8,10,12 \cdot 5,15,17 \cdot 5,20,25$, 30, 40, 50, 70, 100 and 140m with 9-litre van Dorn bottles from the deepest point of the Überlinger See (max. depth $147 \mathrm{~m}$ ), the north-western bight of Lake Constance. Subsampies of $100 \mathrm{ml}$ for cell number and cell volume estimations were immediately preserved with $1 \mathrm{ml}$ Lugol's iodine solution. Subsampies of $100 \mathrm{ml}$ were immediately filtered through cellulose acetate membrane filters $(0 \cdot 2 . \mathrm{um}$ pore-size $)$ for the deterrnination of dissolved reactive silicon.

\section{Cell counts and volume estimations}

Fifty rnillilitres of each of the preserved phytoplankton samples were allowed to settle in sedimentation chambers (Utermöhl 1958) for at least $24 \mathrm{~h}$ and then examined under an inverted microscope. At least 400 individuals of each species dealt with in this study were counted, giving a counting precision of about $\pm 10 \%$ (as coefficient of variation). This standard was maintained even in periods of low population density. For estimation of growth rates a distinction between living and dead cells bad to be made. Knoechel \& Kalff (1978) showed, by autoradiography, that cells with at least one optically distinguishable chloroplast were able to fix carbon. Consequently only cells with no intact chloroplasts and empty frustules were counted as dead.

The nearest standard geometrical solid to the cell shape was selected and appropriate measurements made for calculation of cell volume (Rott 1981). One hundred cells of each species were measured on the first sampling occasion in each year and fifty on subsequent dates. Mean cell volumes with standard deviations are given in Table 2. In no case was a change in cell volume of a species observed during the growth period.

\section{Silicon analysis}

Dissolved reactive silicate was determined by the addition of molybdate and subsequent reduction of the silicomolybdate complex in acid metol-sulphite solution to 'molybdenum blue' by ascorbic acid. Oxalic acid was added before addition of ascorbic acid to eliminate 
interference from phosphate (Strickland \& Parsons 1968). Three replicates per sample were analysed with an Autoanalyser (Technicon Company, Analyser II) using sodium metasilicate nonahydrate as a standard. The lower limit of detection of silicate-silicon was

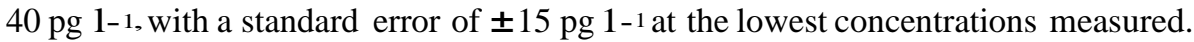

\section{Calculation of silicon consumption by indiv.idual species}

Disappearance of reactive silicon from solution coincided with growth of diatoms and was found to 20m depth in 1979 and 30m in 1980. These layers are defined as the zones of silicon depletion. Silicon that is lost from the dissolved pool is not only transferred to the cell walls of diatoms present in the zone of silicon depletion but also to the cells of diatoms which subsequently sink to deeper water as live or dead cells. In accounting for silicon depletion in the upper layers all of these cells must be considered. Two measures of silicon consumption by diatoms are used: the ratio of silicon loss per unit volume of water to increase in cell numbers per unit volume of water $(\mathrm{RN})$; and the ratio of silicon depletion per unit volume of water to the increase in volume of cells per unit volume of water (Rv). Both are considered to be species-specific. Usually more than one species was growing simultaneously, and the following equations were used:

$$
\begin{aligned}
& \mathrm{Msl}=L_{1}^{\mathbf{I}} \mathrm{RN},(\mathrm{NL}+\mathrm{ND}) ! \\
& \mathrm{M}_{8}=L_{1}^{\prime} \mathrm{Rv},(\mathrm{VL}+\mathrm{VD}) !
\end{aligned}
$$

$A_{81}=$ amount of dissolved silicon in the zone of silicon depletion per unit surface area of lake (mg m-2); $\mathrm{RN}=$ quotient of silicon depletion per unit volume of water to increase in number of cells per unit volume of water (mg cell-1); Rv = quotient of silicon depletion per unit volume of water to increase in volume of cells per unit volume of water (mg mm-3); $N=$ number of cells of species i per unit surface area of lake in the entire water column; $V=$ total volume of cells of species i per unit surface area of lake in the entire water column; $\mathrm{L}=$ living cells; $\mathrm{D}=$ dead cells.

$\mathrm{A}_{81}, N$ and $V$ were determined from analyses and measurements; $\mathrm{RN}$ and $\mathrm{Rv}$ were determined from simultaneaus solution ofthe equations using data for $\mathrm{A}_{81}, N$ and Vfrom at least as many periods between samplings as there were diatom species. Several assumptions and simplifications are necessary.

(i) The equations strictly are not simultaneaus and are related to different sampling intervals. Therefore, $\mathrm{Rv}$ and $\mathrm{RN}$ are considered constant with time. This seems justified since the silicon content of Asterionella formosa, at least, varies only within a small range (Lund 1950; Hughes \& Lund 1962).

(ii) The lake is considered a batch system, for which the external supply of dissolved silicon is negligible compared with decreases through diatom uptake. This is reasonable for 1-week intervals in a lake with a theoretical retention time of water of over 4 years.

(iii) Supply of silicon from deeper water layers to the upper zone of depletion is neglected; even under stratified conditions this restricts the use of the above equations to intervals in which there is rapid growth of diatoms.

(iv) Recycling of silicon by dissolution of empty frustules is considered negligible; only growing populations are considered to affect the concentration of dissolved reactive silicon, therefore negative values for $(\mathrm{NL}+N D) 1$ or $(\mathrm{VL}+V D) 1$ have been set to 
zero; this assumption seems reasonable since only a limited amount of silicon recycling could have occurred in the time available (Bailey-Watts 1976b).

The more rapidly diatoms are growing between two sampling dates, the smaller is the error resulting from the last three assumptions. Neglecting external supply and recycling leads to an underestimation of Rv and RN. On the other hand errors inherent in counting-neglect of frustules or fragments incorporated into detritus particles or lost by grazing-lead to an overestimation of $\mathrm{Rv}$ and $\mathrm{RN}$.

\section{Calculation ofgrowth rates and loss rates}

Calculation of growth rates is complicated because changes in population density are always the net result of concomitant growth and loss. Knoechel \& Kalff (1979) have recently used autoradiography to estimate species-specific photosynthesis and hence the potential absolute growth rates. Grim (1939) used the number of dead cells and cells sunk from the euphotic layer as well as the active population in his estimate of growth rates. A four-compartment model based on Grim's model for the fate of diatom cells was used here. Let: $\mathrm{NL}(\mathrm{eu})=$ total number ofliving cells in the euphotic zone per unit area oflake;

$\mathrm{NL}(\mathrm{a})=$ total number ofliving cells in the aphotic zone per unit area oflake;

$N \mathrm{~N}(\mathrm{eu})=$ total number of dead cells in the euphotic zone per unit area of lake;

$N D(a)=$ total number of dead cells in the aphotic zone per unit area of lake.

$\mathrm{NL}(\mathrm{euJ}$ represents the potentially active population and all increase in total number of cells has to be explained by cell divisions in the $\mathrm{NL}(\mathrm{eu})$ fraction. For the potentially active population the net rate of population increase $(k)$ between times $t_{1}$ and $t_{2}$ is:

$$
\begin{gathered}
k=\ln \mathrm{NL}(\mathrm{eu}) \mathrm{l}-\ln \mathrm{NL}(\mathrm{eu}) \mathrm{l} \\
\boldsymbol{t} \boldsymbol{Z}-\mathrm{tl}
\end{gathered}
$$

$k$ can either be positive (increasing population) or negative (decreasing population). It is generally lower than the growth rate (p), which is a function ofthe number of cell divisions. Only when no losses occur does $k$ equal $p$. Therefore $k$ is a combined rate, comprising the rate of growth (p) and the rate ofloss $(\ddot{A})$, which must be either positive or zero;

$$
k=p-\ddot{A} \text {. }
$$

All cells lost from the potentially active population are assumed tobe found in one ofthe three other compartments:

$$
\begin{aligned}
& \mathrm{NL}(\mathrm{eu})-+\mathrm{NL}(\mathrm{a}) \text { (sinking ofliving cells); } \\
& \mathrm{NL}(\mathrm{eu})-+\mathrm{Nn}(\mathrm{eu}) \text { (death of cells in the euphotic zone); } \\
& \mathrm{Nn}(\mathrm{eu})-+\mathrm{ND} \text { (a) (sinking of dead cells); } \\
& \mathrm{NL}(\mathrm{a})-+\mathrm{Nn}(\mathrm{a}) \text { (death of cells in the aphotic zone). }
\end{aligned}
$$

Any increase in a succeeding compartment must be explained either by a decrease in a preceding compartment or by production of new cells by compartment $N \mathrm{~L}(\mathrm{eu})^{\prime}$ All increases in the compartments $\mathrm{Nn}(\mathrm{eu}) \cdot \mathrm{NL}(\mathrm{a}) \cdot \mathrm{Nn}(\mathrm{a})$ that are not covered by losses in preceding compartments must be attributed to production of new cells that are then lost from the $\mathrm{NL}(\mathrm{eu})$ compartment. Adding these cells to $\mathrm{NL}(\mathrm{eu})$ will give Ncorr, $\bullet$ which now can replace NL(euhin eqn 3 and thus allow an estimate ofthe growth rate:

$$
\begin{aligned}
& p^{\prime}=\text { 1n } \mathrm{Ncorr}_{2}-\mathbf{l n} \mathrm{NL}(\mathrm{eu}) \mathrm{l} \\
& t z-\mathrm{tl}
\end{aligned}
$$


$l i^{\prime}$ is only a mmunum estimate of $! \mathrm{J}$, because several processes (sedimentation to the bottom, break-up of empty frustules, incorporation into detritus particles and grazing) make cells uncountable. When these processes lead to a decrease of the sum of NL!eul + NL(a) + $\mathrm{Nn}<$ eul + Nocal• ! J' can be negative, which is, of course, theoretically impossible for a growth rate. In such cases the values for $1 \mathrm{~J}$ have been considered to be zero. The minimum estimate for $\ddot{A}\left(\ddot{A}^{\prime}\right)$ can now be obtained from the difference between $k$ and \#'. It was not possible to differentiate between cells that died prior to or following Sedimentation. Therefore no attempts have been made to separate the loss rates into separate death rates and Sedimentation rates.

\section{RESULTS}

\section{Diatom growth and silicon depletion during spring and summer 1979 and 1980}

The concentration of dissolved reactive silicon in the surface water decreased significantly during two periods in both years under study. These phases coincided with the spring and summer growth periods of diatoms (Sommer 1981a, b) (Fig. 1). In a clear-water phase in June, when high grazing pressure by zooplankton kept phytoplankton population density low, there was an increase in concentration of dissolved reactive silicon, but not to the concentration prior to the spring diatom growth. The lowest concentration of dissolved reactive silicon was reached during the summer growth period. Minimum concentration in
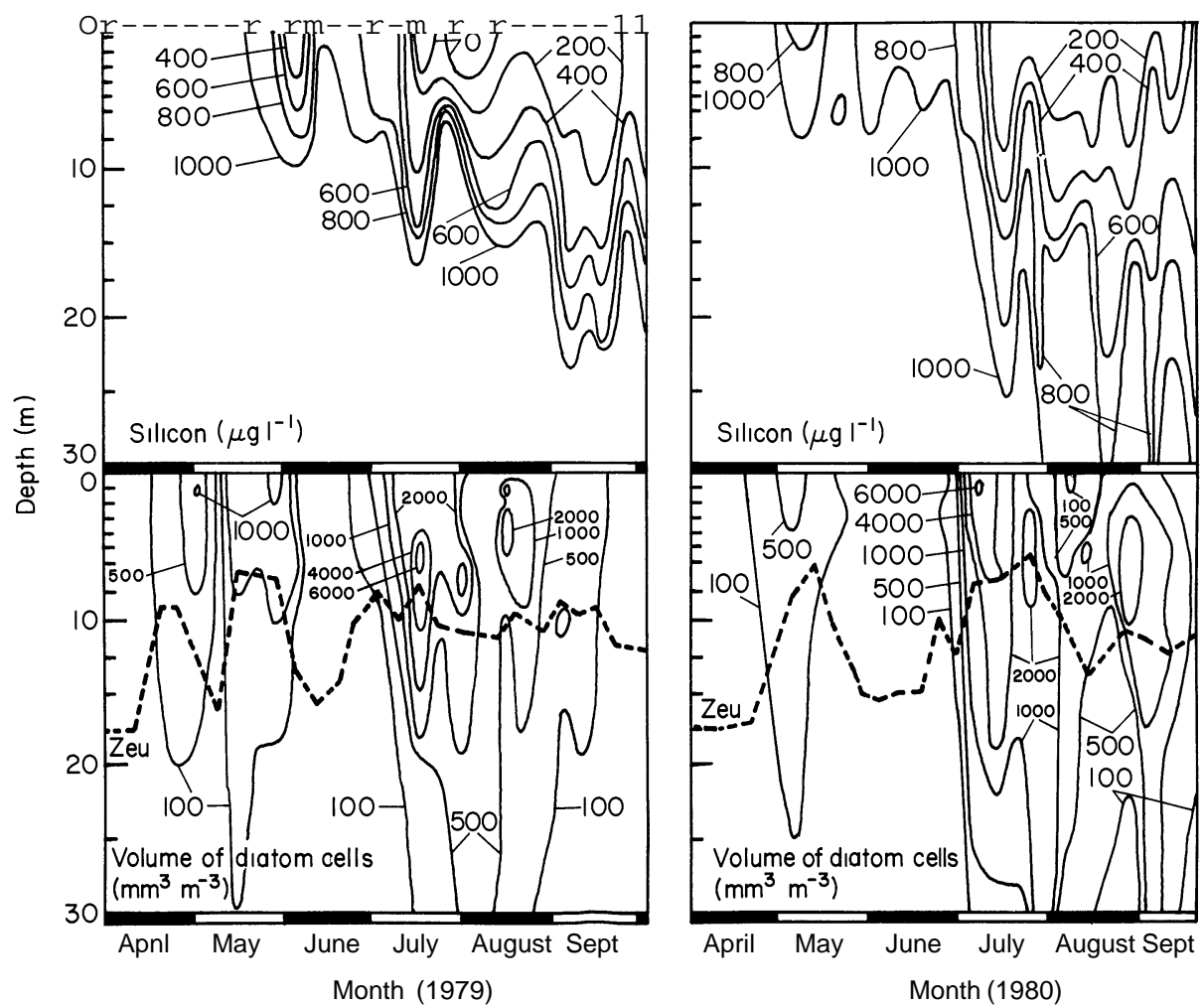

Fra. 1. Depth-time diagrams of dissolved reactive silicon concentration ( $\mathrm{Jg} I-1)$ and cell volumes of diatoms per unit volume of water $\left(\mathrm{mm}^{3} \mathrm{~m}-3\right)$ in the spring and summer growth phases of diatoms in 1979 and 1980 in Lake Constance. The broken line indicates the depth of the euphotic zone. 
1979 was below detection Ievel, but the minimum in 1980 was 74 p.g I-1 on 14 July at a depth of $4 \mathrm{~m}$. This was weil below the 500 p.g I-1 given by Lund (1950) as the minimum concentration for Asterione/la formosa growth, the saturation constant $\left(\mathrm{K}_{11} \mathrm{~m}\right)$ of 820 p.g $1-1$, and the half-saturation constant $\left(\mathrm{K}_{8}\right)$ of 110 p.g I-1 for silicon limited growth of Asterione/la formosa given by Tilman \& Kilham (1976). The autumnal diatom growth (Sommer 1981a, b) was not reflected in either year by the concentration of dissolved silicon because resupply of silicate to the euphotic zone by deep mixing during that period compensated for uptake by diatoms. The autumnal growth period is thus not considered here. The depth to which silicon depletion, coinciding with diatom growth, was noted, extended below the conventional euphotic zone depth (defined as the depth at which only $1 \%$ of surface light energy remains). This could have resulted from some vertical mixing despite thermal stratification (for temperature data see Stabel \& Tilzer (1981)), uptake of silicon below the compensation depth of photosynthesis, or an underestimate of euphotic zone depth by the convention.

\section{Growth and decline of dominant diatom species}

In 1979 two diatom species, Stephanodiscus hantzschii f. pusillus Grun. and Synedra acus Kz. were the dominant diatoms in spring, whereas in 1980 only Stephanodiscus hantzschii was plentiful (Fig. 2). In both years the summer diatom plankton was first dominated by Asterionellaformosa. In 1979 there was then a succession from A.formosa to Fragilaria crotonensis Kitton and thereafter to Stephanodiscus binderanus Krieger; in 1980, from Asterione/la formosa to Stephanodiscus binderanus and then to Fragilaria crotonensis. Besides those species only Stephanodiscus hantzschii f. pusillus and Melosira granulata Ralfs. were significant; all other diatom species contributed less than $0 \cdot 1 \%$ to the total volume of diatom cells (Fig. 3). The maximum population densities of living Asterionella formosa cells, on 17 July 1979 and 14 July 1980, were reflected in marked minimal concentrations of dissolved reactive silicon. In the following week the total number of $A$. formosa cells increased, but the number of living cells began to decrease. Thereafter growth of $A$. formosa was not observed. A small second growth pulse at the end of summer 1980 was unimportant in terms of the volume of cells produced. Numerical population

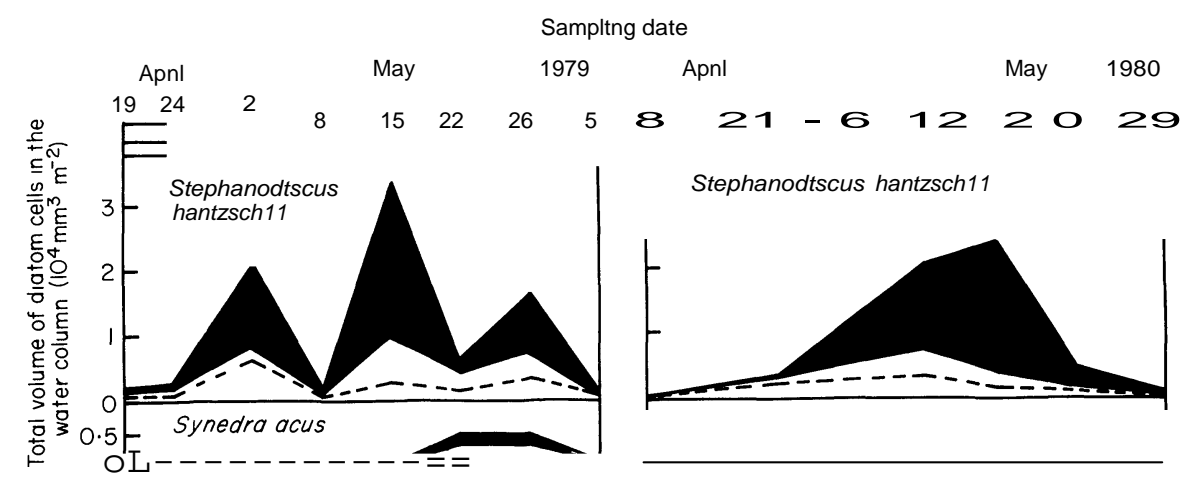

Fro. 2. Changes in the total volume of diatoms in the volume of water contained under $1 \mathrm{~m}^{2}$ of surface area of Lake Constance in the springs of 1979 and 1980. The filled areas indicate dead cells in the entire water column, and the unfilled areas living cells. The broken line separates the volumes of cells in the euphotic zone (under the line) from those in the aphotic zone (above the line). 


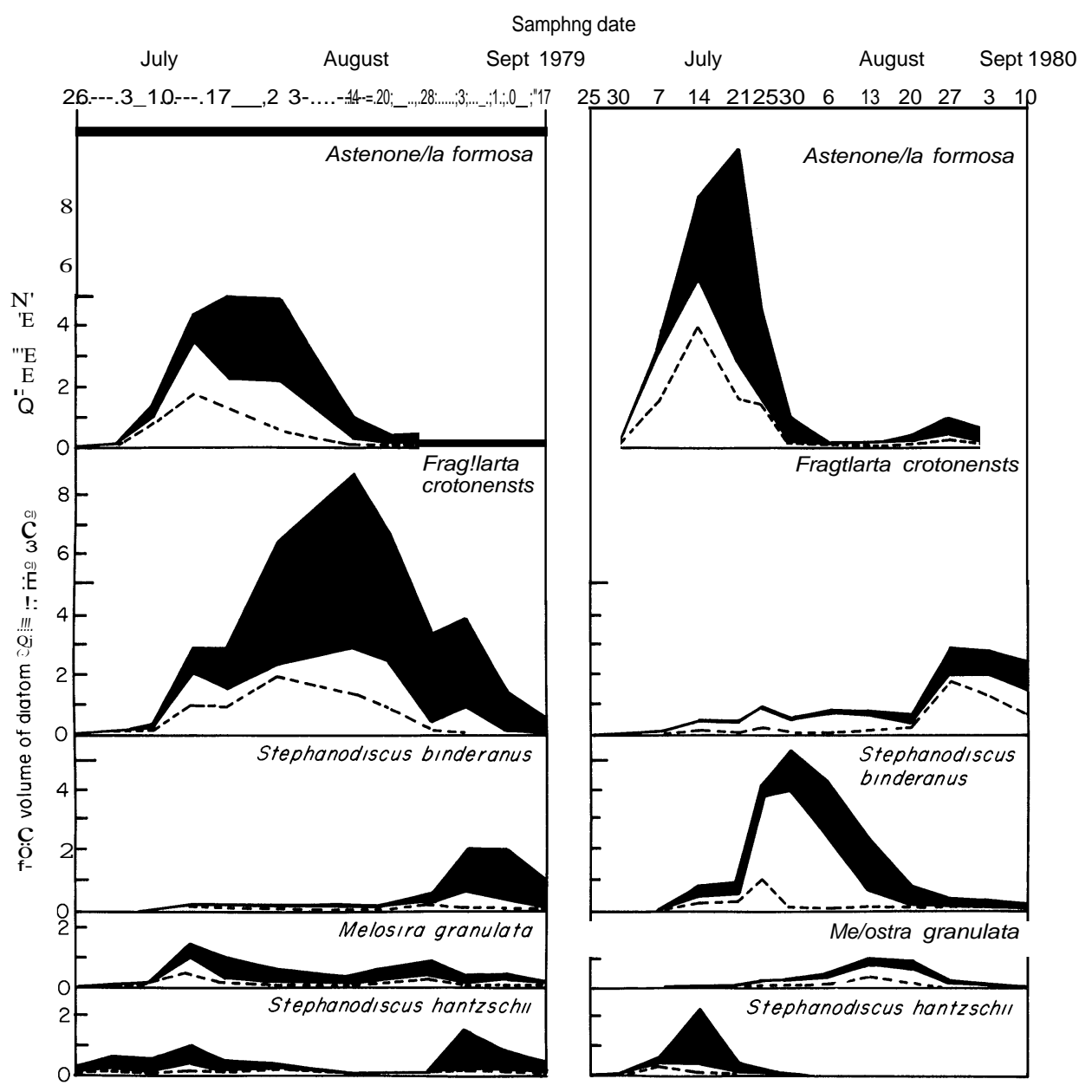

FIG. 3. Changes in the total volume of diatoms in the volume of water contained under $1 \mathrm{~m}^{2}$ of surface area of Lake Constance in the summers of 1979 and 1980. Symbols as in Fig. 2.

density of $A$. formosa increased continuously, however, over three consecutive sampling periods from 6 to 27 August 1980, by a factor of eight.

In both years, increase in population density of Fragilaria crotonensis and of Stephanodiscus binderanus stopped in the week following the mid-July minimum in concentration of dissolved silicon. Recovery of dissolved silicon concentration was observed on 23 July 1979 and 21 July 1980 and gave rise to a second growth pulse of Fragilaria crotonensis in both years and of Stephanodiscus binderanus in 1980.

\section{Silicon consumption by individual species}

Through solution of the equations given in Table 1, the quotients of silicon consumption per million cells (RN) and per unit cell volume were obtained for 1979 and 1980 and are given in Table 2. For most species only one value could be obtained per year. More than one value for $\mathrm{Rv}$ and for $\mathrm{RN}$ were available for Stephanodiscus hantzschii in both years and for Fragilaria crotonensis in 1980. Although derived from different sampling intervals (Table 1), there was little variation among the values obtained for particular species. There 
TABLE 1. Equations used for calculation of the silicon contents (a) per $10^{6}$ cells (RN mg) and (b) per unit cell volume (Rv mg mm-3) for diatom species in Lake Constance. The left-hand sides of the equations give the amount of dissolved silicon (g) lost from a column of the euphotic zone, $1 \mathrm{~m}^{2}$ in cross-sectional area, during the appropriate period. The right-hand sides give the products of the numbers (x 109) or total cell volume $\left(\mathrm{mm}^{3} \mathrm{x} 10 \mathrm{~B}\right)$ in the same volume of water and RN or Rv respectively. Symbols: A, Asterionella formosa; F, Fragilaria crotonensis; M, Melosira granulata; STB, Stephanodiscus binderanus; STH, Stephanodiscus hantzschii; SY, Synedra acus.

(a) Calculation of RN

Period Equation

1979

4 April-2 May

8-15 May

$2 \cdot 57=370 \mathrm{RN}(\mathrm{STH})$

15-22 May

$5 \cdot 20=640 \mathrm{RN}(\mathrm{STH})+0 \cdot 179 \mathrm{RN}(\mathrm{SY})$

22-29 May

$1 \cdot 55=213 \mathrm{RN}(\mathrm{SY})$

3-10July

$1 \cdot 67=200 \mathrm{RN}(\mathrm{STH})$

10-17 July

23 July-1 Aug

8-14 Aug

$5.43=104 \mathrm{RN}(\mathrm{STH})+0 \cdot 3 \mathrm{RN}(\mathrm{SY})+4 \cdot 10 \mathrm{RN}(\mathrm{F})+22 \cdot 4 \mathrm{RN}(\mathrm{A})+3 \cdot 53 \mathrm{RN}(\mathrm{M})$

$8 \cdot 04=78 \mathrm{RN}(\mathrm{STH})+25 \cdot 7 \mathrm{RN}(\mathrm{F})+45 \cdot 3 \mathrm{RN}(\mathrm{A})+2 \cdot 69 \mathrm{RN}(\mathrm{M})+9 \cdot 23 \mathrm{RN}(\mathrm{STB})$

$4 \cdot 02=34 \mathrm{RN}(\mathrm{F})$

$3 \cdot 11=22 \mathrm{RN}(\mathrm{F})$

28 Aug-3 Sept

$5 \cdot 93=304 \mathrm{RN}(\mathrm{STH})+0 \cdot 182 \mathrm{RN}(\mathrm{SY})+10 \cdot 3 \mathrm{RN}(\mathrm{F})+75 \cdot 3 \mathrm{RN}(\mathrm{STB})$

1980

8-21 April

$0 \cdot 272=53 \mathrm{RN}(\mathrm{STH})$

$1 \cdot 81=373 \mathrm{RN}(\mathrm{STH})$

21 April-6 May

30 June-7 July

$6 \cdot 15=149 \mathrm{RN}(\mathrm{STH})+0.621 \mathrm{RN}(\mathrm{F})+50 \cdot 5 \mathrm{RN}(\mathrm{A})+0.068 \mathrm{RN}(\mathrm{M})+1 \cdot 78 \mathrm{RN}(\mathrm{STB})$

7-14 July

21-25 July

$11 \cdot 2=34 \cdot 2 \mathrm{RN}(\mathrm{STH})+3.9 \mathrm{RN}(\mathrm{F})+76.7 \mathrm{RN}(\mathrm{A})+0.868 \mathrm{RN}(\mathrm{M})+41 \cdot 4 \mathrm{RN}(\mathrm{STB})$

25 July-6 Aug

$4.63=4.45 \mathrm{RN}(\mathrm{F})+4.86 \mathrm{RN}(\mathrm{M})+170 \mathrm{RN}(\mathrm{STB})$

13-27 Aug

$1 \cdot 68=1 \cdot 84 \mathrm{RN}(\mathrm{M})+68 \cdot 7 \mathrm{RN}(\mathrm{STB})$

$3 \cdot 76=22 \cdot 6 \mathrm{RN}(\mathrm{F})+12 \cdot 2 \mathrm{RN}(\mathrm{A})$

(b) Calculation of Rv

Period

Equation

1979

14 April-2 May

8-15 May

15-22 May

22-29 May

3-10July

10-17 July

23 July-1 Aug

1-14 Aug

28 Aug-3 Sept

$2 \cdot 57=18 \cdot 5 \mathrm{RV}(\mathrm{STH})$

$5 \cdot 20=32 \cdot 1 \mathrm{Rv}(\mathrm{STH})+0 \cdot 36 \mathrm{Rv}(\mathrm{SY})$

$1 \cdot 55=4 \cdot 27 \mathrm{RV}(\mathrm{SY})$

$1 \cdot 67=10 \mathrm{Rv}(\mathrm{STH})$

$5 \cdot 43=5 \cdot 24 \mathrm{Rv}(\mathrm{STH})+0.6 \mathrm{Rv}(\mathrm{SY})+4 . \mathrm{J} \operatorname{Rv}(\mathrm{F})+15 \cdot 7 \mathrm{Rv}(\mathrm{A})+1 \cdot 77 \mathrm{Rv}(\mathrm{M})$

$8.04=3.99 \mathrm{Rv}(\mathrm{STH})+25 \cdot 7 \mathrm{Rv}(\mathrm{F})+31 \cdot 7 \mathrm{Rv}(\mathrm{A})+1 \cdot 34 \mathrm{Rv}(\mathrm{M})+1 \cdot 85 \mathrm{Rv}(\mathrm{STB})$

$4 \cdot 02=33 \cdot 9 \mathrm{RV}(\mathrm{F})$

$3 \cdot 11=22 \cdot 4 \mathrm{RV}(\mathrm{F})$

$5 \cdot 93=15 \cdot 2 \mathrm{RV}(\mathrm{STH})+0 \cdot 36 \mathrm{RV}(\mathrm{SY})+10 \cdot 3 \mathrm{RV}(\mathrm{F})+15 \cdot 1 \mathrm{RV}(\mathrm{STB})$

1980

8-21 April

$0 \cdot 272=2 \cdot 66 \mathrm{RV}(\mathrm{STH})$

21 April-6 May

$1 \cdot 81=18 \cdot 7 \mathrm{RV}(\mathrm{STH})$

$6 \cdot 15=7 \cdot 41 \mathrm{Rv}(\mathrm{STH})+0.62 \mathrm{Rv}(\mathrm{F})+35 \cdot 3 \mathrm{Rv}(\mathrm{A})+0.034 \mathrm{Rv}(\mathrm{M})+0.36 \mathrm{Rv}(\mathrm{sTB})$

30 June-7 July

7-14 July

21-25 July

25 July-6 Aug

13-27 Aug

$11 \cdot 2=1 \cdot 71 \mathrm{Rv}(\mathrm{STH})+3 \cdot 91 \mathrm{Rv}(\mathrm{F})+53 \cdot 7 \mathrm{Rv}(\mathrm{Al}+0 \cdot 43 \mathrm{Rv}(\mathrm{M})+8 \cdot 27 \mathrm{Rv}(\mathrm{STB})$

$4.63=4.45 \mathrm{Rv}(\mathrm{F})+2 \cdot 43 \mathrm{Rv}(\mathrm{M})+33.9 \mathrm{Rv}(\mathrm{STB})$

$1 \cdot 68=0.92 \mathrm{Rv}(\mathrm{M})+13 \cdot 7 \mathrm{Rv}(\mathrm{STB})$

$3 \cdot 76=22 \cdot 6 \operatorname{Rv}(\mathrm{F})+8 \cdot 52 \operatorname{Rv}(\mathrm{A})$

were great interspecific differences in $\mathrm{RN}$ but values for $\mathrm{Rv}$ ( $\mathrm{Si}, \mathrm{mg} \mathrm{mm-3)}$ varied only between 0.10 and 0.25 for all species except Synedra acus (Rv $=0.36 \mathrm{mg} \mathrm{mm}-3$ ), which was only a sub-dominant species in Lake Constance. For all species, values of Rv and RN were slightly smaller in 1980 than in 1979, and for Asterionella formosa the values for 1980 were markedly smaller than those for 1979. This may be because of greater replenishment of dissolved silicate from the catchment and deep water in 1980. In 1979 the 
TABLE 2. Volume and silicon content of cells of the major phytoplankton diatom species in Lake Constance, compared with similar data for the same species in other lakes.

\begin{tabular}{|c|c|c|c|c|}
\hline & $\begin{array}{c}\text { Volume } \\
\text { of cell } \\
\text { (,um } \pm \text { S.D.) }\end{array}$ & $\begin{array}{l}\text { Silicon content } \\
\text { per unit } \\
\text { cell volume } \\
\text { (mg mm-3) } \\
\text { (Rv) }\end{array}$ & $\begin{array}{l}\text { Silicon content } \\
\text { per } 106 \text { cells } \\
\text { (mg) (RN) }\end{array}$ & $\begin{array}{l}\text { Year (present study) } \\
\quad \text { or source }\end{array}$ \\
\hline \multirow[t]{6}{*}{ Asterionellaformosa } & $700 \pm 150$ & $0 \cdot 27$ & $0 \cdot 19$ & 1979 \\
\hline & & $0 \cdot 15$ & $0 \cdot 10$ & 1980 \\
\hline & $320--440$ & $0 \cdot 12-0 \cdot 16$ & $0 \cdot 05-0 \cdot 07$ & Einseie \& Grim (1938) \\
\hline & & & $0 \cdot 045-0 \cdot 08$ & Hughes \& Lund (1962) \\
\hline & 450 & $0 \cdot 16$ & $0 \cdot 07$ & Bailey-Watts (1976a) \\
\hline & 750 & $0 \cdot 11$ & $0 \cdot 08$ & Happey (1970) \\
\hline \multirow[t]{3}{*}{ Fragilaria crotonensis } & $1000 \pm 230$ & $0 \cdot 12-0 \cdot 14$ & $0 \cdot 12-0 \cdot 14$ & 1979 \\
\hline & & $0 \cdot 10$ & $0 \cdot 10$ & 1980 \\
\hline & 800 & $0 \cdot 09-0 \cdot 14$ & $0 \cdot 07-0 \cdot 11$ & Einseie \& Grim (1938) \\
\hline \multirow{3}{*}{ Melosira granulata } & $500 \pm 90$ & $0 \cdot 22$ & $0 \cdot 11$ & 1979 \\
\hline & & $0 \cdot 18$ & $0 \cdot 09$ & 1980 \\
\hline & 420 & $0 \cdot 14$ & $0 \cdot 06$ & Einseie \& Grim (1938) \\
\hline \multirow[t]{2}{*}{ Stephanodiscus binderanus } & $200 \pm 50$ & $0 \cdot 13$ & $0 \cdot 026$ & 1979 \\
\hline & & $0 \cdot 11$ & $0 \cdot 022$ & 1980 \\
\hline \multirow[t]{2}{*}{ Stephanodiscus hantzschii } & $50 \pm 20$ & $0 \cdot 14-0 \cdot 17$ & $0 \cdot 07-0 \cdot 085$ & 1979 \\
\hline & & $0 \cdot 10$ & $0 \cdot 005$ & 1980 \\
\hline \multirow[t]{2}{*}{ Synedra acus } & $2000 \pm 480$ & $0 \cdot 36$ & $0 \cdot 72$ & 1979 \\
\hline & 3200 & $0 \cdot 19$ & $0 \cdot 61$ & Einseie \& Grim (1938) \\
\hline
\end{tabular}

summer growth phase of diatoms occurred during a period of decreasing water Ievels but in 1980 it coincided with increasing water Ievels. In 1980 the thermal stratification was weaker throughout the whole summer period than in 1979 (M. Tilzer, W. Geller, H.-H. Stabel \& U. Sommer unpublished). The two years had markedly different hydrographic regimes, and so the only small differences in estimates of RN and Rv indicate a relatively small sensitivity of the calculation method to the potential errors indicated above. There was reasonable agreement between our values and those taken from the Iiterature (Table 2), despite the variety of methods used to obtain them (digestion of natural diatom populations by Einseie \& Grim (1938) and Bailey-Watts (1976a), and of cultured diatoms by Hughes \& Lund (1962)).

\section{Diatompopulation dynamics in the summers of 1979 and 1980}

Although no distinction can be made between different components of the loss rate, the proportion contributed by dead cells to the total cell number in the euphotic zone can provide some indication of the time course of cell mortality. Changes in the proportians of dead cells in the euphotic zone are compared with those of $k, p^{\prime}$ and ..1! for the three dominant species of the summer diatom p1ankton (Fig. 4). Where disso1ved reactive silicon concentration was minimal in mid-July the growth rates (p') of Fragilaria crotonensis and Stephanodiscus binderanus declined to zero. In cantrast Asterionellaformosa still had a positive $p^{\prime}$ in the interval immediately following the minimum concentration of dissolved silicon, which suggests that cell division continued. The loss rate (Ä'), however, was higher than the growth rate $\left(\mathrm{p}^{\prime}\right)$, thus giving a decrease in the number ofliving cells in the euphotic zone.

For Fragilaria crotonensis and Stephanodiscus hantzschii the proportion of dead cells in the euphotic zone continuously and slowly increased during the summer with no sudden increase when the dissolved silicon concentration was low. The large number of dead cells 

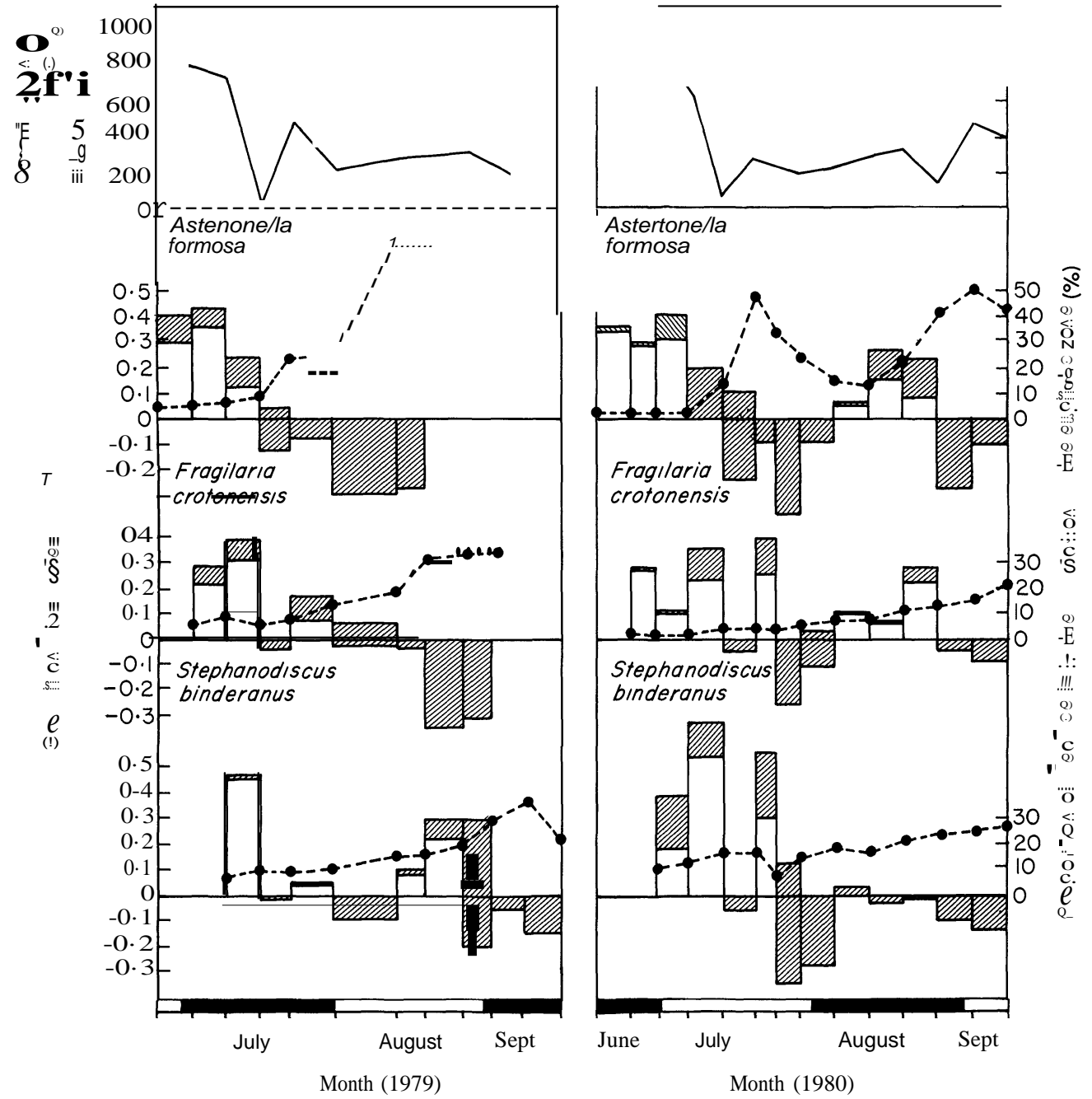

FIG. 4. Growth rates and loss rates of dominant diatoms during the summers of 1979 and 1980 in Lake Constance compared with the average concentration of dissolved reactive silicon in the euphotic zone (--) and the proportion of dead cells in the total number of cells of a given species in the euphotic zone (---) - The upper Iimits of the bar diagrams give minimum estimates of growth rate (JJ.' day- 1); the lower Iimit of the shaded area gives the observed net rate of increase (k day-1); the extent of the shaded area thus gives the Ioss rate (A.' day- 1).

of Fragilaria crotonensis in the whole water column in August 1979 (Fig. 3) was not characteristic of the euphotic zone, but resulted from accumulation of dead cells at 100 and $140 \mathrm{~m}$ depth. In contrast, there was a sharp increase in the proportion of dead cells of Asterionella formosa in the euphotic zone following periods when dissolved silicon concentrations were minimal.

\section{DISCUSSION}

In analysing the interdependence of diatarn growth and dissolved reactive silicon concentration at the species Ievel, we have investigated the following between-species 
differences: the amount of silicon used to produce cells and how growth rates and loss rates are affected by the minimum of silicon concentration that occurs during the summer.

Horizontal heterogeneity in the distribution of phytoplankton might have influenced the results of the calculations of both species-specific silicon consumption and of growth and loss rates, because the data used were derived from a single vertical profile on each sampling date. However, temporal variation of diatom crops far exceeded possible spatial variation in such an exposed and surface-mixed lake as Lake Constance; between weekly sample collections, diatom population densities sometimes differed by more than one order of magnitude (Figs 2 and 3). Furthermore, results for 1979 and 1980 are in good agreement, and the silicon consumption we calculated agrees with values obtained by different methods, as recorded in the literature.

No marked between-species differences in the quotient of silicon consumption to production of cell volume (Rv) were found. Except for Synedra acus, all species studied could produce about the same cell volume per unit silicon consumed. The succession of diatoms in Lake Constance cannot therefore be explained as a sequence from species with high silicon requirements to species which require less silicon during a period of decreasing concentration of dissolved reactive silicon.

Conversely, between-species differences in response to short periods of marked silicon deficiency do provide a possible explanation for the species sequence observed in summer. Cell division of Asterionellaformosa continued when the concentration of dissolved silicon reached its minimum, but many more cells died. In contrast, Fragilaria crotonensis and Stephanodiscus binderanus ceased division but mortality did not increase markedly, and growth began again after the concentrations of dissolved silicon had risen. Catastrophic mortality associated with silicon depletion was suggested by Lund (1950) in his classic study of Asterionella formosa in several English lakes. He argued that silicon depletion might lead to mass death of the population if the cells are stimulated by light to continue cell division in the absence of sufficient silicon for wall formation. In contrast, La Zerte (1980) compared the end of an Asterionella formosa population growth in Frains Lake (U.S.A.) with the stationary phase in a batch culture, with growth stoppage by silicon limitation. This explanation is more in agreement with the general understanding of nutrient-limited growth that has developed under the influence of application of the Michaelis-Menten relationship to nutrient-growth interactions. It assumes diminishing growth rate with decreasing concentration ofthe limiting nutrient and excludes mortality.

Moed (1973) has given experimental verification to Lund's concept. He has found, in cultures, that a combination of light and silicon deficiency is lethal for Asterionella formosa, while absence of light, and thus of cell-division, enables it to survive. As far as Asterione/la formosa is concerned our findings agree with those of Lund and Moed. Fragilaria crotonensis and Stephanodiscus binderanus seem to react like Asterionella formosa in the dark in Moed's experiment. It is still unknown which physiological mechanisms might prevent these species from continuing to divide under silicon-deficient conditions.

\section{ACKNOWLEDGMENTS}

We thank members of the Deutsche Forschungsgemeinschaft sponsored project 'Carbon cycle in Lake Constance' for help in sampling, Professor M. Tilzer for reviewing the manuscript and Mrs Hauswald for technical assistance in determination of silicon. 


\section{REFERENCES}

Balley-Watts, A. E. (1976a). Planktonic diatoms and some diatom-silica relations in a shallow eutrophic Scottish loch. Freshwater Biology, 6, 69-80.

Balley-Watts, A. E. (1976b). Planktonic diatoms and silica in Loch Leven, Kinross, Scotland: a one month silica budget. Freshwater Biology, 6, 203-213.

Baumert, H. (1979). System analysis of silica-diatom interaction. Internationale Revue der gesamten Hydrobiologie, 64,457-473.

Einsele, W. \& Grim, J. (1938). Über den Kieselsäuregehalt planktischer Diatomeen und dessen Bedeutung für einige Fragen ihrer Ökologie. Zeitschriftfür Botanik, 23,345-590.

Grim, J. (1939) Beobachtungen am Phytoplankton des Bodensees (Obersee) sowie deren rechnerische Auswertung. Internationale Revue der gesamten Hydrobiologie, 39, 193-315.

Happey, C.M. (1970). The effects of stratification on phytoplanktonic diatoms in a small body of water. Journal of Ecology, $58,635-\{; 51$.

Hughes, J. L. \& Lund, J. W. G. (1962). The rate of growth of Asterionella formosa Hass. in relation to its ecology. Archiv.[qr Mikrobiologie, 42, 117-129.

Jt rgensen, E. G.(1955). Variations in the silica content of diatoms. Physiologia Plantarum, 8,840-845.

Knoechel, R. \& Kalft', J. (1978). An in situ study of the productivity and population dynamics of five freshwater planktonic diatom species. Limnology and Oceanol(raphy, 23, 195-218.

LaZerte, B. (1980). The stationary phase or a natural population of Asterionellaformosa (Bacillariophyceae) limited by silica. Archivfür Hydrobiologie, 90,26-38.

Lund, J. W.G. (1950). Studies on Asterionellaformosa Hass. II. Nutrient depletion and the spring maximum. Journal ofEcology, 38, 1-35.

Moed, J. R. (1973). Efl'ect of combined actwn of light and silicon depletion on Asterionella formosa Hass. Verhandlungen des internationalen Vereinsfür Limnologie, 18, 1367-1374.

Mohammed, A. A. \& MüDer, H.(1981).Zur Nährstofftimitierung des Phytoplanktons im Bodensee. Archiv für Hydrobiologie, Supplement, 59,151-191.

Rott, E.(1981).Some results from phytoplankton intercalibrations. Schweizerische Zeitschriftfür Hydrologie, 43, 34- $\{; 2$.

Sommer, U. (1981a). The roJe of $r$ - and K-selection in the succession of phytoplankton in Lake Constance. Acta Oecologica-Oecologia Generalis, 2,327-342.

Sommer, U. (1981b). Phytoplanktonbiocoenosen und -Sukzessionen im Bodensee/Überlinger See. Verhandlungen der Gesellschaftfür Okologie, 9, 33-42.

Stabel, H.-H. \& Tilzer, M. M. (1981). Nährstoffkreisläufe im Überlinger See und ihre Beziehungen zu den biologischen Umsetzungen. Verhandlungen der Gesellschaftfür Okologie, 9, 23-32.

Strickland, J. D. H. \& Parsons, T. R. (1968). A practical handbook of seawater analysis. Bulletins of the Fisherfes Research Board ofCanada, 169,1-311.

Tilman, D. \& KDham, S. S. (1976). Phosphate and silicate growth and uptake kinetics of the diatoms Asterionella formosa and' Cyclotella meneghiniana in batch and semicontinuous culture. Journal of Phycology, 12, 375-483.

Utermöhl, H. (1958). Zur Vervollkommnung der quantitativen Phytoplankton-Methodik. Mitteilungen des internationalen Vereinsfür theoretische und angewandte Limnologie, 9, 1-38.

(Received 17 Apri/1982) 